\title{
EVALUATING THE CUSTOMER SATISFACTION ON THE SERVICE QUALITY OF TULANGAN SIDOARJO NEW MARKET PARKING
}

\author{
Kurnia Hadi Putra ${ }^{1}$, Ita Suhermin Ingsih ${ }^{2}$, Ramadhani Stevian Darmawan ${ }^{3}$ \\ ${ }^{1,3}$ Civil Engineering Department, Institut Teknologi Adhi Tama Surabaya, Indonesia \\ ${ }^{2}$ Civil Engineering Department, University of Islam Malang, Malang Indonesia \\ e-mail: kurnia_putra@itats.ac.id
}

\begin{abstract}
The evaluation of customer satisfaction becomes a vital aspect for investigating the satisfaction level of customer toward the parking service at Tulangan New Market. This research aimed at improving the service quality and performance of parking facilities at Tulangan New Market. It also intended for investigating the characteristic of customer who frequently use the parking facilities. To ease the data analysis, the researcher used Important Perfomance Analysis (IPA) method. The assessment upon 60 respondent concerning the satisfaction and interest was portrayed in quadrant 1, whereas quadrant 2 only had 1 point of questionnaire instrument. Quadrant 3 in the cartesian diagram only gained 2 questionnaire instrument and quadrant 4 had 8 questionnaire instrument. Accordingly, the respondents were satisfied with the performances of 8 questionnaire instrument because quadrant 4 earned the most points. The conclusion, the customers of parking felt satisfied with existing service of parking facility.
\end{abstract}

Keywords: Parking Facilities; Customer Satisfaction; IPA.

\section{Introduction}

Sidoarjo Regency is a district adjacent to the city of Surabaya and is located in the Province of East Java. Sidoarjo is famous for the disaster which at that time was very famous, namely the Lapindo mud [1] and at this time by the government and local residents it was made a very famous tourist attraction [2]. Sidoarjo also has a very rapid development in various fields. With a total area of Sidoarjo Regency, which is $714.24 \mathrm{~km}^{2}$ with a total population of 2,262,440 people in 2019 , according to [14]. Sidoarjo, which is located close to the city of Surabaya, also has great potential to improve the regional economy of course. Many people of Sidoarjo who work in Surabaya or who are studying make this area able to continue to develop in all fields of trade, industry, business, education and tourism.

Renovation of the Reinforcement market has been planned since 2011. With the Government of Sidoarjo as the land owner, investors have provided the construction of the Tulangan Market for renovation to investors. And at this time the Tulangan Market is managed by PT. Wahyu Graha Persada. The renovation of the Tulangan Market itself was carried out from December 2017 to completion in July 2019. With the concept of a more modern market renovation, it is hoped that visitors will be more comfortable visiting the market. Tulangan New Market has 2 floors, on the ground floor or one it has a booth of 160 units and 102 units of closed kiosks, while on the second floor it has 117 units of stalls [15]. One of the changes or new innovations given in the renovation of this Tulangan Market is a vehicle parking area for market visitors. It is hoped that the visitors can increase and feel comfortable visiting the market. So that economic turnover can increase. In the past, the parking for visitors to the Tulangan Market was all on-street parking. The unavailability of parking lots so that visitors are forced to park on-street, where on-street parking causes traffic impacts and does not look neat.

Parking facilities are a means of supporting transportation and vehicles. This facility is at the destination that must be provided. This is very important in the scope of the transportation system. 
If it is not available, then the road space is forced to be used as a parking space. Public parking is parking that uses land, roads or vacant land with parking management carried out by the local government. Most public parking uses part of the road as a public parking area owned by the local government [13].

So with the construction of this new parking lot, there needs to be a customer satisfaction review so that we know how the quality of the parking service at the Tulangan Market is after the renovation. Previously, customers had to park on-street and after being renovated, now customers can park their vehicles off-street. And to analyze how do market visitors respond to this problem.

\section{Methods}

The following are the stages carried out by researchers in study:

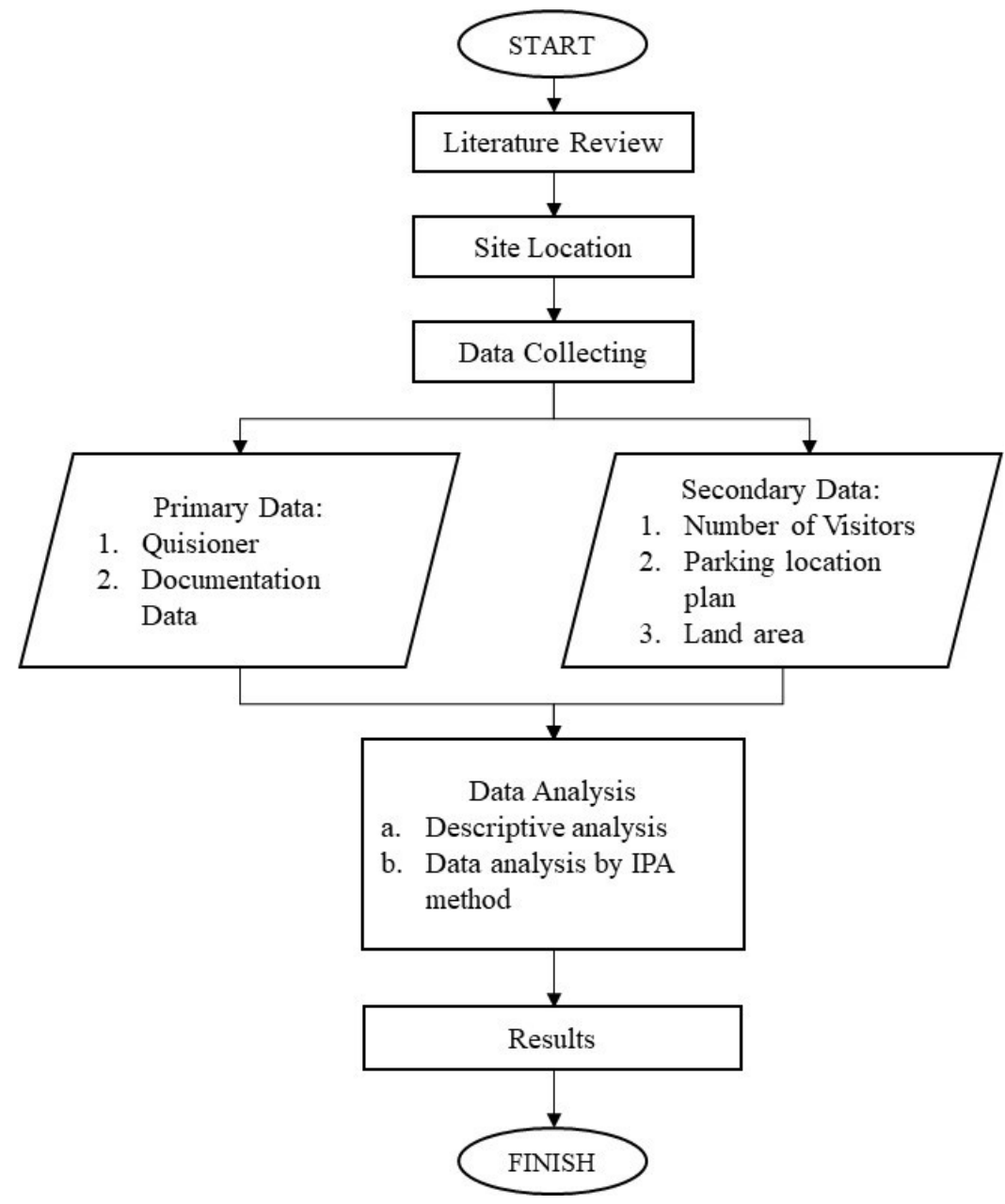

Figure 1. Steps of Research

\subsection{Research Location}

The research location is the place where the research or data search is carried out. Determining the right location, the data obtained is in accordance with what is desired and does not miss the goal. This research will be conducted at the Sidoarjo Tulangan New Market. The location is in the district of Tulangan, Sidoarjo. 


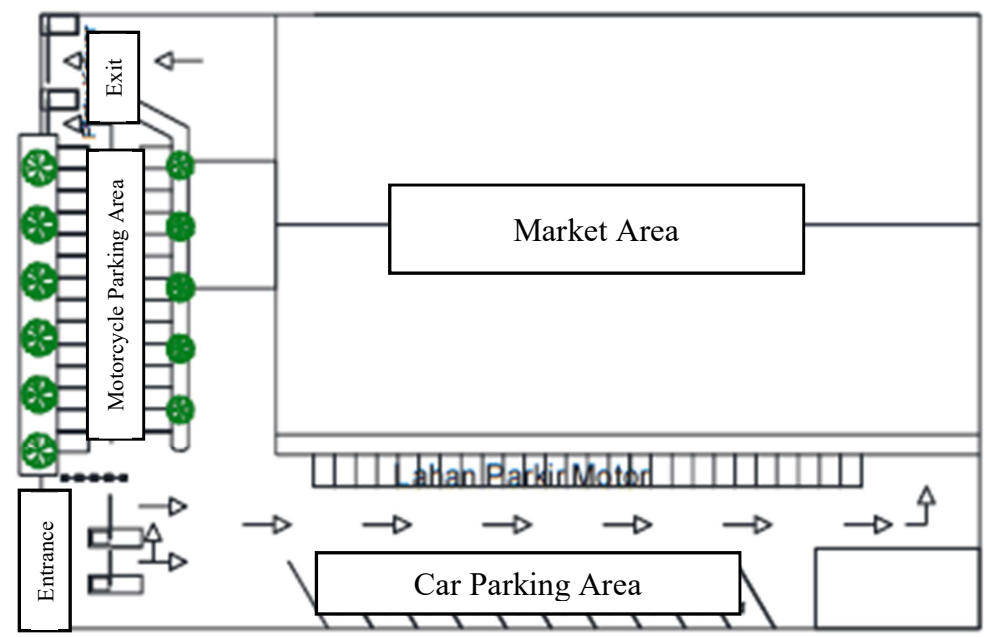

Figure 2. Research Site Plan Tulangan New Market

\subsection{Data Collecting Method}

In compiling a research, data collection is one of the important things to do with the aim of obtaining all the information needed to achieve a goal of the research itself. In this study there are two sources of data obtained by researchers, namely primary data and secondary data.

a. Primary Data

Primary data collection was carried out by direct site survey by observing, distributing questionnaires and interviews. Primary data is obtained from the first source without being processed and is original, which will later be processed to get the expected results later. The primary data needed in this study include:

- Parking visitor characteristics data. Parking is where the vehicle or means of transportation is in a temporary state of immobility. The parking lot is the location where the vehicle stops at the destination [3]. The visitor characteristics data is the visitor profile data of market. This data serves to find out everyone who uses the market parking lot. This characteristic data will certainly be different for each individual. This data includes the age of visitors, gender, how often they visit the market and the distance from the house to the market.

- Visitor Satisfaction Data

Visitor satisfaction data is useful data in assessing the level of customer satisfaction with parking management at the Tulangan New Market. From this data, it will be processed so that it can determine the level of satisfaction of parking visitors.

b. Secondary Data

Secondary data collection is obtained by collecting data or information from a second party or other parties. The data was obtained from several sources, but has been processed further. This secondary data is also important in getting the desired research results later. Secondary data is supporting data so that the research data is complete and the research runs optimally. Without secondary data, the research cannot be said to be maximal. The secondary data needed in this study include:

- Number of Visitors

Data on the number of visitors [4] is how many individuals use parking services at the Tulangan New Market. Data on the number of parking visitors is used in determining the sample. This sample will determine how many survey objects use a questionnaire.

- Location Plan and Land Area 
The location plan is a map or layout where the research is carried out. It is important for the reader to know the floor plan and also the location where this research was conducted. So it can also be used as an overview of the layout and area of the location reviewed in the study.

\subsection{Data Analysis Method}

a. Descriptive Analysis

In this study, the research method chosen was descriptive analysis. The definition of descriptive analysis is a method that is useful for describing the object under study through data and samples that have been collected so that the data and samples are easily understood by readers and the general public. This method aims to provide a systematic description of the facts that relate between variables from the data that has been processed and obtained.

\section{b. IPA (Importance Performance Analysis)}

This analysis serves to determine service performance [5][6][7] based on the level of customer satisfaction. Customer satisfaction data was obtained using a questionnaire that had been distributed regarding the level of satisfaction and importance. After the data is obtained, it will be processed and analyzed. In this study, the data analysis method used is The Important Performance Analysis (IPA) method [8].

\section{Result and Discussion}

In this study, 60 respondents were used from parking customers at the Tulangan New Market at the time the questionnaire distribution survey was conducted. And to fill out the questionnaire as supporting data in the research conducted. The determination of 60 respondents was obtained from the total population of customers of the Tulangan New Market Sidoarjo market by using the slovin formula to determine the number of samples. For data processing, the IPA analysis method is used to obtain data from the results of data processing. Which later after using this IPA analysis method can be known the level of satisfaction and importance of the 17 questionnaire instruments. This IPA analysis uses a Cartesian diagram to find out the results. This Cartesian diagram has 4 quadrants, each quadrant has a different meaning, the most data that enters the quadrant is the result later. This diagram has $\mathrm{x}$ and $\mathrm{y}$ axes, each of which is the average value of satisfaction for $\mathrm{y}$, which is the average value of importance. Data from the results of processing the respondent's assessment on the questionnaire that has been distributed, then the data is entered into a Cartesian diagram to get the results of which quadrant is filled with the most instruments. To obtain the results of the planned research, the data obtained from the survey results need to be analysed. So it can be seen the level of customer satisfaction at the Tulangan New Market. IPA analysis [9] is to find out which instruments need to be improved to meet customer satisfaction. The data that has been processed will later be described into a Cartesian diagram to find out which questionnaire instrument has the most in the quadrant of the Cartesian diagram. In the Cartesian diagram [10][11][12], this IPA analysis has 4 quadrants with 2 lines that intersect perpendicularly, where the $\mathrm{x}$-axis is for the average satisfaction rating while the $y$-axis is for the average value of interest. From the data that has been obtained in the detailed survey, it has been processed to be entered into a Cartesian diagram to find out the results of the satisfaction and interest values of the customers of the Tulangan New Market parking lot which can be seen in Figure 3. 


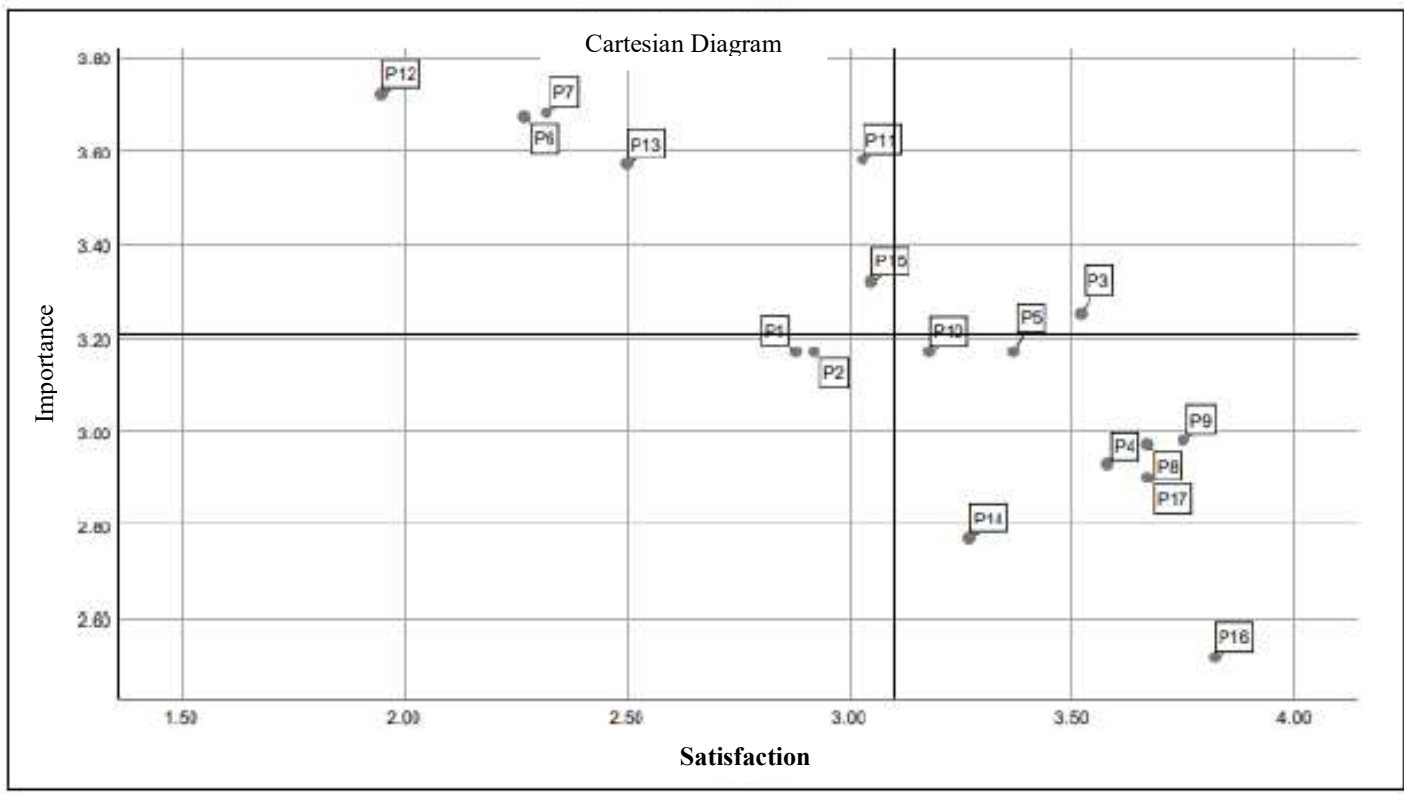

Figure 3. Cartesian Diagram

Note:

1. Not often get parking

2. Often go around looking for parking

3. Availability of parking spaces

4. Wide entrance

5. Wide parking way

6. The dexterity of officers in helping to find parking

7. Dexterity of officers guiding parking

8. Parking ticket as the identity of the vehicle

9. Checking the ticket at the time of exit

10. Safety when walking in the parking area

11. Safety from the vehicle

12. Availability of helmet storage

13. Availability of security personnel

14. Circulation conditions of parking area

15. Parking lighting conditions

16. Distance from parking lot to market

17. Compatibility of parking rates

In the Cartesian diagram that has been made as above, the instrument of the questionnaire has different assessments so that the Cartesian diagram occupies different quadrants depending on the satisfaction and interests of the respondents. So that it can be seen the value of the level of customer satisfaction and which points still need to be improved. From the Cartesian diagram above, it can be explained which instrument occupies which quadrant, which is explained as follows:

1) Quadrant I

In this first quadrant, the instruments have a high interest from parking customers but low satisfaction from parking customers. So that the interests of parking customers have an important factor in influencing parking services. So it need to be improved for instrument in this quadrant. Those included in the first quadrant are dexterity in parking attendants 
helping to find parking, dexterity of officers guiding parking, security of vehicles, availability of helmet storage, availability of security officers and parking lighting conditions.

\section{2) Quadrant II}

The attributes that are in the second quadrant in the Cartesian diagram show that the assessment of the respondents, namely parking customers, has a high satisfaction value but also has a high importance. Parking customers still expect attributes that are in quadrant two but with high satisfaction so that this performance needs to be maintained. There is only one attribute that is included in quadrant 2, namely the availability of parking space.

3) Quadrant III

Quadrant 3 (three) is filled by two assessment attributes. Questionnaire attributes that are in this quadrant have the intention of having a low priority so that parking customers rate this attribute as less important and customer satisfaction is also low. So parking customers do not really have an interest in this attribute and customers judge they are not satisfied with this attribute.

4) Quadrant IV

In quadrant 4 (four) it is stated that the assessment of the respondents is in terms of customer satisfaction, the satisfaction is high, while the interest is low. In this quadrant, the attributes that enter are not considered important for parking customers because they are very satisfied with the services provided by the manager. Those that enter into quadrant 4 are the condition of the width of the entrance, the condition of the width of the exit, the parking ticket as the identity of the vehicle, check the ticket when exiting, security when walking in the parking area, the condition of the circulation of parking vehicles, the distance of the parking lot to the market and the suitability of parking fees.

\section{Conclusions}

From the research above, it can be concluded that the results of the level of customer satisfaction based on the IPA method were known that several instruments need performance evaluation and some important things that in the first quadrant of the Cartesian diagram, namely dexterity in parking attendants helping to find parking, dexterity of officers guiding parking, security of vehicles, availability of helmet storage, availability of security officers and parking lighting conditions. For instruments in quadrant two, which is a high value between satisfaction and importance, namely the availability of parking spaces. Instruments in third quadrant are often not getting parking and often or not turning around looking for parking. Meanwhile, the highest number of instruments entered the fourth quadrant, namely the condition of the width of the entrance, the condition of the width of the exit, the parking ticket as the identity of the vehicle, examination of the ticket at the time of exit, security when walking in the parking area, the condition of the circulation of parking vehicles, the distance of the parking lot to the market, and the suitability of parking rates. So, for parking customer satisfaction services at the Tulangan New Market, the most points are 8 points into quadrant 4 , which means that of the 17 questionnaire instruments, customers are satisfied with the services provided by the parking manager for the new Tulangan New Market. And if the manager makes improvements or adds points to the parking facility instrument that is included in the first quadrant, it is very possible for the quality of service for parking customers to increase because it has high customer interests. For instruments in the second and third quadrants, their services can be more maintained. 


\section{References}

[1] E. P. ELIKA, R. RESNAWATY, and A. S. GUTAMA, "Bencana Sosial Kasus Lumpur Pt. Lapindo Brantas Sidoarjo, Jawa Timur," Pros. Penelit. dan Pengabdi. Kpd. Masy., vol. 4, no. 2, pp. 205-216, 2017, doi: 10.24198/jppm.v4i2.14272.

[2] R. A. Firmansyah and K. H. Putra, "Analisis Tingkat Kepuasan Pengguna Transportasi Umum 'Suroboyo Bus' Rute Halte Rajawali-Terminal Purabaya Dengan Metode Importance Performance Analysis (Ipa)," Pros. Semin. Teknol. Perencanaan, Perancangan, Lingkung. dan Infrastruktur, vol. 1, no. 1, pp. 1-6, 2019, [Online]. Available: https://ejurnal.itats.ac.id/stepplan/article/view/711.

[3] Direktorat Bina Sistem Lalu Lintas dan Angkutan Kota, "Pedoman Perencanaan dan Pengoprasian Fasilitas Parkir.” p. 187, 1998.

[4] C. K. Dewi and N. L. P. S. E. Setyarini, "Analisis Tingkat Kepuasan Pengguna Terhadap Fasilitas Parkir Mobil Mall Puri Indah,” JMTS J. Mitra Tek. Sipil, vol. 3, no. 3, p. 659, 2020, doi: $10.24912 /$ jmts.v3i3.8386.

[5] M. Yola and D. Budianto, "Analisis Kepuasan Konsumen Terhadap Kualitas Pelayanan dan Harga Produk pada Supermarket dengan Menggunakan Metode Importance Performance Analysis (IPA)," J. Optimasi Sist. Ind., vol. 12, no. 1, p. 301, 2016, doi: 10.25077/josi.v12.n1.p301-309.2013.

[6] K. Cv and A. Maulana, "Jurnal benefit vol. 1 no. 1 juli 2019," vol. 1, no. 1, pp. 23-34, 2019.

[7] A. O. Akbar Nagara and A. Emaputra, "Analisis Kepuasan Konsumen terhadap Pelayanan Barbershop dengan Metode Service Quality (Servqual) dan Importance Performance Analysis (IPA) Studi Kasus XYZ Barbershop,” J. Rekayasa Ind., vol. 2, no. 2, pp. 97-104, 2020, doi: 10.37631/jri.v2i2.183.

[8] S. Liawatimena, M. F. Amanda, H. Handoko, and H. Hendry, "Evaluasi Customer Relationship Management pada Supermarket Hero di Jakarta Timur," The Winners, vol. 3, no. 2, p. 112, 2002, doi: $10.21512 /$ tw.v3i2.3843.

[9] R. Natassia, "Importance Performance Analysis (Ipa) Dimensi Kualitas Pelayan Jasa Rumah Sakit Selasih Terhadap Kepuasan Pasien,” Economica, vol. 1, no. 1, pp. 78-85, 2012, doi: 10.22202/economica.2012.v1.i1.107.

[10] A. Suhendra and D. Prasetyanto, "Kajian Tingkat Kepuasan Pengguna Trans Metro Bandung Koridor 2 Menggunakan Pendekatan Importance-Performance Analysis," J. Online Inst. Teknol. Nas., vol. 2, no. 2, pp. 59-70, 2016.

[11] G. A. Immanuel and R. Setiawan, "Implementasi Metode Importance Performance Analysisuntuk Pengukurankualitas Sistem Informasi Akademik,” KURAWAL J. Teknol. Inf. dan Ind., vol. 3, no. 2, pp. 181-190, 2020.

[12] L. Pratama, A. V. S. Hubeis, and N. H. Pandjaitan, "Analisis Tingkat Kepuasan Anggota dan Strategi Pengembangan Koperasi (Studi Kasus Koperasi Kredit Sehati Jakarta),” Manaj. IKM J. Manaj. Pengemb. Ind. Kecil Menengah, vol. 12, no. 1, p. 104, 2017, doi: 10.29244/mikm.12.1.104-115.

[13] Direktorat Bina Sistem Lalu Lintas dan Angkutan Kota, "Pedoman Perencanaan dan Pengoprasian Fasilitas Parkir." p. 187, 1998.

[14] K. Sidoarjo, "Kabupaten Sidoarjo," Kabupaten Sidoarjo, 2018. [Online]. Available: Classroom.google.com/u/0/c/Mzk5MDk0NDE3NDkz/gb/sort-first-name. [Accessed 22 December 2021].

[15] D. Sidoarjo, "Disperindag Sidoarjo," Disperindag Sidoarjo, 2018. [Online]. Available: https://sidoarjo.e-pasar.id/pasardetail/13. [Accessed 20 December 2021]. 